МІНІСТЕРСТВО ОСВІТИ І НАУКИ УКРАЇНИ

ЕКОНОМІЧНА БЕЗПЕКА ПІДПРИЕМСТВА

МЕТОДИЧНІ РЕКОМЕНДАЦІЇ

до вивчення дисципліни

для студентів галузі знань 05 «Соціальні та поведінкові науки» спеціальності 051 «Економіка» спеціалізації «Економіка підприємства»

Київ - 2016 
Економічна безпека підприємства: метод. рекомендації до вивчення дисципліни для студентів галузі знань 05 «Соціальні та поведінкові науки» спеціальності 051 «Економіка» спеціалізації «Економіка підприємства» / уклад. М.В. Шашина - К.: КПІ, 2016. - 45 с.

Ухвалено Вченою Радою факультету менеджменту та маркетингу Національного технічного університету України «КПІ» Протокол № 10 від 30 травня 2016 року

Рецензент: к.е.н., доц. Корогодова О.О.

Укладач: к.е.н., доц. Шашина М.В.

Відповідальний за випуск: Круш П.В., проф., к.е.н.

Видання подається в авторській редакції 
Програму навчальної дисципліни «Економічна безпека підприємства» складено відповідно до освітньо-професійних програм підготовки бакалаврів факультету менеджменту та маркетингу галузі знань 0305 «Економіка та підприємництво».

Навчальна дисципліна належить до циклу дисциплін гуманітарної та соціально-економічної підготовки за вибором студентів і базується на фундаментальних знаннях, сформованих у ході навчання «Економіки підприємства», «Правознавства», «Основ економічної теорії» та забезпечує подальше навчання професійно орієнтованих кредитних модулів «Оцінка вартості підприємства», «Інвестування», «Капітал підприємства: формування та використання». Формує економічні знання, вміння, здатності, які $є$ підгрунтям ефективної організації господарської діяльності підприємств, а також озброює студентів вміннями застосовувати ці знання для розв'язання практичних задач з підвищення ефективності роботи підприємств при застосуванні методів оцінки та уникнення загроз підприємства.

Предметом дисципліни $\epsilon$ економічна безпека підприємства, їі основні показники та методи забезпечення.

Дисципліна «Економічна безпека підприємства» актуальна і їі роль визначається спроможністю формувати у студентів професійних навичок роботи на державних та приватних підприємствах, навичок самостійної роботи 3 законодавчими матеріалами, додатковою літературою, свідомо оцінювати конкретні ситуації, прагнення до набуття та збагачення знань.

Основними видами навчання є лекції та практичні заняття. Ці форми дають можливість у повному обсязі вивчити новий матеріал, закріпити його, розвивати практичні навички та контролювати знання.

Навчальним планом передбачається самостійна робота студентів, тематика якої направлена на вивчення законодавчих та інструктивних матеріалів, роботу з навчальними посібниками, з матеріалами періодичних видань, розрахунок задач і виконання тестів різного рівня складності. 
Метою викладання навчальної дисципліни $є$ надання студентам базових знань i методів економічного аналізу процесів та явищ, що становлять небезпеку підприємству; формування системних уявлень про закономірності та тенденції розвитку світової i вітчизняної школи визначення та формування системи захисту економічної безпеки підприємству, про економічний розвиток методів оцінки економічної небезпеки підприємства; визначення наукового внеску окремих шкіл і напрямів в економічну теорію та їхнього впливу на економічну безпеку держави; формування сучасного економічного мислення та світогляду студентів щодо систем захисту підприємтсва.

Згідно 3 вимогами освітньо-професійної програми студенти після засвоєння навчальної дисципліни мають продемонструвати такі результати навчання:

знання:

- $\quad$ основних понять економічної безпеки підприємства;

- показників оцінки стану економічної безпеки підприємства;

- $\quad$ методів забезпечення економічної безпеки підприємства;

- видів стратегій економічної безпеки;

- $\quad$ основні загрози економічній безпеці підприємства вміння:

- $\quad$ досліджувати стан підприємства та рівня його економічної

безпеки;

- $\quad$ визначати загрози економічній безпеці конкретного підприємства;

- $\quad$ аналізувати стратегії економічної безпеки підприємства;

- $\quad$ розраховувати показники стану економічної безпеки підприємства.

досвід:

- обгрунтування очікуваної економічної ефективності прийнятих рішень на мікрорівні;

- проведення робити аналітичних досліджень економіки підприємства 


\section{1. ПРОГРАМА НАВЧАЛЬНОЇ ДИСЦИПЛІНИ}

Програма дисципліни «Економіка підприємства» включає наступні модулі:

\section{Модуль1}

Змістовний модуль 1. Змістовно - типологічна характеристика економічної безпеки господарюючого суб'єкту

Тема 1.1 Загальні теоретичні положення економічної безпеки підприємства

Мета та функціональні цілі економічної безпеки підприємства. Основні функції економічної безпеки підприємства. Структурні елементи і схема організації економічної безпеки підприємства.

Лimepamypa: 1 [p.18]; 9 [p.3]; 2 [p.2]

Тема 1.2 Основні напрями організації економічної безпеки на підприємстві

Характеристика основних функціональних складових економічної безпеки підприємства: фінансової, інтелектуально-кадрової, технікотехнологічної.

Характеристика основних функціональних складових економічної безпеки підприємства: політико-правової, силової, екологічної.

Лimepamypa: 1 [р.18]; 9 [p.3]; 2 [р.2]

\section{Модуль 2}

Змістовний модуль 2. Система економічної безпеки підприсмства

Тема 2.1 Охорона законних інтересів підприємств: конфіденційна інформація і комерційна таємниця

Визначення інформації, конфіденційної інформації, комерційної таємниці. Класифікація комерційної таємниці. Організація заходів на підприємстві щодо встановлення комерційної таємниці.

Лimepamypa: 1 [p.18]; 10; 12 [p.1]; 5 [p.2]; 7 [p.4]

Тема 2.2 Промислова розвідка та промисловий шпіонаж 
Поняття промислова розвідка, поняття промисловий шпіонаж: проведення, організація, механізм здійснення та ознаки.

Лimepamyра: $11 ; 4 ; 6 ; 3$.

Тема 2.3 Економічні злочини, які впливають на стан економічної безпеки підприємництва

Види злочинів. Характеристика та ознаки злочинів, що вчиняються службовими особами. Характеристика та ознаки злочинів, які вчиняються шляхом незаконного використання підприємцем своїх прав або їх порушення. Злочини в кредитно-фінансовій та податковій сферах. Злочини, пов'язані 3 безпосередньою діяльністю на ринку, зокрема, щодо монополістичних дій та обмеження конкуренції. Злочини, пов'язані 3 незаконним одержанням i розголошенням відомостей, що становлять комерційну або банківську таємницю

Лimepamypa: 1 [р.18]; 10; 7[р.4]

Тема 2.4 Технологічні та функціональні дії щодо захисту від погроз економічної безпеки

Методи вивчення контрагентів. Аналіз умов укладання договорів та контрактів. Правила роботи 3 конфіденційною інформацією. Захисту комп'ютерних систем.

Лimepamypa: 1 [p.18]; 4; 7 [p.4].

\section{Модуль 3}

Змістовний модуль 3. Механізм забезпечення економічної безпеки підприємства

Тема 3.1 Принципи та етапи забезпечення економічної безпеки підприємства

Етап стратегічного планування та прогнозування економічної діяльності підприємства. Етап оперативної оцінки рівня економічної безпеки.

Лimepamypa: 1 [p.18]; 9 [p.3]; 8 [p.3].

Тема 3.2 Структура механізму забезпечення економічної безпеки підприємства 
Механізм забезпечення економічної безпеки підприємства. Структура механізму забезпечення економічної безпеки підприємства. Функції структурних елементів механізму забезпечення економічної безпеки підприємства

Лimepamypa: 4 [p.5]; 12; 9 [p.3]

\section{3. ТЕМИ ПРАКТИЧНИХ ЗАНЯТЬ}

Таблиия 3.1

\section{Теми практичних занять 3 дисципліни «Економічна безпека підприємства»}

\begin{tabular}{|c|c|}
\hline \multirow{2}{*}{ Назви розділів і тем } & \multicolumn{1}{|c|}{ Кількість годин } \\
\cline { 2 - 3 } & \multicolumn{1}{|c|}{ Денна форма навчання } \\
\cline { 2 - 3 } & \multicolumn{1}{|c|}{6.030504} \\
\hline \hline \multicolumn{2}{|c|}{ Змістовний модуль 1. 3містовно - типологічна характеристика економічної безпеки } \\
господарюючого суб'скту
\end{tabular}




\begin{tabular}{|c|c|}
\hline 1 & 2 \\
\hline $\begin{array}{c}\text { Тема 3.2. Структура } \\
\text { механізму забезпечення } \\
\text { економічної безпеки підприсмства }\end{array}$ & 4 \\
\hline Разом за розділом 3. & 8 \\
\hline Всього годин & 22 \\
\hline
\end{tabular}

\section{4. РЕКОМЕНДАЦІЇ ДО ПРОВЕДЕННЯ ПРАКТИЧНИХ ЗАНЯТЬ}

\section{ПРАКТИЧНЕ ЗАНЯТТЯ 1}

Teмa: Загальні теоретичні положення економічної безпеки підприємства

Мета заняття: систематизація теоретичних знань щодо характеристик основних елементів функціональних складових економічної безпеки підприємства.

\section{План проведення заняття:}

1. Характеристика та основні елементи функціональних складових економічної безпеки підприємства.

2. Порівняльна характеристик економічних систем та елементів економічної безпеки, які властиві командно-адміністративній та ринковій системам.

Ключові поняття: економічна безпека, економічна безпека підприємства, економічна безпека підприємніџтвва, економічна безпека держави, економічна безпека регіону, система економічної безпеки підприємства, загрози, інтереси, захист, принципи економічної безпеки підприємства.

Лimepamypa: 1 [p.18]; 9 [p.3]; 2 [p.2].

\section{Питання для дискусії та завдання.}

1. Дайте визначення наукової категорії «безпека».

2. Визначіть роль і значення економічної безпеки підприємства в сучасних умовах розвитку економіки України.

3. Наведіть дату прийняття Закону «Про національну безпеку» в США?

4. Розкрийте основні етапи еволюції поняття «економічна безпека». 
5. Розкрийте основні етапи еволюції поняття «економічна безпека» в нашій країні.

6. Що таке «глобальна економічна безпека»?

7. Що ви розумієте під терміном «міжнародна економічна безпека»?

8. Виділіть основні фактори впливу на рівень безпеки регіону.

9. Дайте визначення наукової категорії «економічна безпека країни».

10. Дайте визначення наукової категорії «економічна безпека підприємства».

11. Сформулюйте основні концептуальні положення управління економічною безпекою підприємства.

12. Наведіть приклади факторів, які впливають на стан економічної безпеки підприємства.

13. Яке визначення поняття «економічна безпека підприємства» $\epsilon$ найбільш комплексним?

14. Визначення категоріального апарату дисципліни.

15. Якими концептуальними положеннями управління економічною безпекою підприємства ви б доповнили поданий перелік?

16. Які елементи світового досвіду забезпечення економічної безпеки підприємства доцільно запровадити в Україні та як їх адаптувати під особливості ведення вітчизняного бізнесу?

\section{Завдання 1.}

Визначте основні функціональні цілі економічної безпеки

\begin{tabular}{|l|c|}
\hline Функціональні цілі & $\begin{array}{c}\text { Напрям прояву функціональної цілі } \\
\text { економічної безпеки }\end{array}$ \\
\hline & \\
\hline
\end{tabular}

Завдання 2.

Визначіть основні загальні риси понять «фінансове вирівнювання» та «економічна безпека регіону».

Завдання 3.

Сформулюйте еволюційні етапи поняття «економічна безпека країни». 
Проведіть аналіз взаємозв'язку категорій «економічна безпека підприємства» та «ризик».

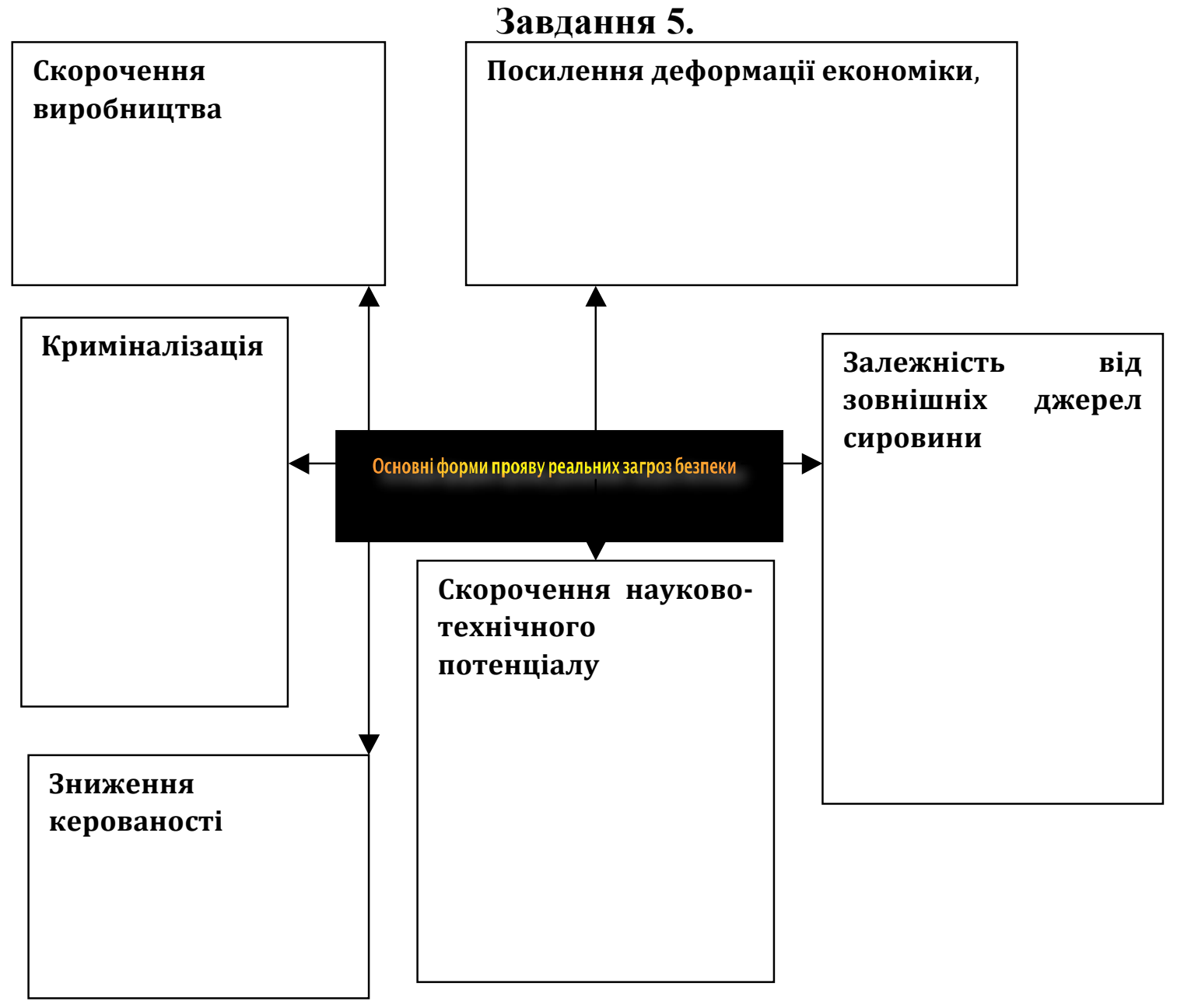

Тестові завдання для перевірки знань:

1. В основі економічної безпеки підприсмства лежить:

Захист інтересів працівників даного підприємства;

Підвищення рівня виробництва даного підприємства;

Відстоювання конкурентоспроможності даного підприємства;

Нейтралізація факторів, які підривають стійкість економічного механізму;

Забезпечення належного рівня ресурсної бази даного підприємства.

2. Формування власної системи захисту економічної безпеки властиве:

Малим підприємствам; 
Середнім підприємствам

Великим підприємствам;

Державним підприємствам;

Приватним підприємствам.

\section{3. Мотиваційними інтересами називають:}

3.1 Інтереси які суб'єктивно публічно висуває як мотив своїх вчинків;

3.2 Інтереси, під якими можна розуміти фактичні інтереси в тому вигляді, в якому вони виявлені та зафіксовані спостерігачами;

3.3 Інтерес, які на думку спостерігачів, найкращим чином відповідають потребам суб'єкта;

3.4 Інтереси, якими керується сам суб'єкт і які свідомо чи несвідомо направляють його вчинки;

3.5 Вся сукупність вище зазначених груп.

4. Яке із зазначених джерел не відносить до зовнішніх реальних загроз підприємства:

Посилення деформації економіки;

Скорочення науково-технічного потенціалу;

Криміналізація;

Конкуренція;

Залежність від зовнішніх джерел сировини.

5. В західні практиці функції „кредит-бюро” полягають:

В оцінці ринкової ситуації, огляді сектору ринку окремої галузі або регіону;

Наданні послуг з погашення заборгованостей перед кредиторами;

Аналізі політичної та економічної ситуації;

В оцінці криміногенної ситуації в окремих регіонах;

Аналізі кредитного ринку.

\section{ПРАКТИЧНЕ ЗАНЯТТЯ 2}

\section{Tема: Оцінка рівня економічної безпеки підприсмства}

Мета заняття: визначення показників часткового та сукупного 
критеріїв економічної безпеки підприємства, складання функціональної карти економічної безпеки підприємства.

\section{План проведення заняття:}

1. Визначення показників часткового та сукупного критеріїв економічної безпеки підприємства.

2. Складання функціональної карти економічної безпеки підприємства.

Ключові поняття: функиінальні складові економічної безпеки підприємства: фінансова, техніко-технологічна, політико-правова, екологічна, силова, інтелектуально-кадрова, інформаційна; сукупний крітерій економічної безпеки, частковий критерій економічної безпеки, функиіональна карта підприємтсва, загальнозазнані витрати, відвернені витрати, сукупний збиток.

Лimepamypa: 1 [p.18]; 9 [p.3]; 2 [p.2].

\section{Питання для дискусії}

1. Особливості формування служби економічної безпеки підприє мства на вітчизняних підприємствах.

2. Як повинні забезпечувати належний рівень економічної безпеки підприємства основні його підрозділи?

3. Як захиститись від неправомірних дій контрагентів підприємства?

4. Як сформувати систему показників для проведення оцінки та аналізу економічної безпеки підприємства?

5. Проаналізувати взаємозв'язок та взаємообумовленість складо вих інформаційно-аналітичного забезпечення економічної безпеки підприємства.

\section{Завдання 1.}

Сформулюйте основні функціональні ознаки ознаки фінансової складвої економічної безпеки підприємства

\begin{tabular}{|l|l|}
\hline Функціональна складова & Змістовні ознаки \\
\hline & \\
\hline
\end{tabular}

Завдання 2. 
Поясніть зміст та процедуру оцінювання сукупногокритерію економічної безпеки підприємтсва

$$
\text { СKEБ }=\sum_{i=1}^{N} K_{i} d_{i}
$$

\section{Завдання 3.}

Поясніть зміст та процедуру оцінювання часткового функціонального критерію економічної безпеки підприємства

$$
4 \Phi K=\frac{3_{\text {sid }}}{B+3_{\text {заг }}} \rightarrow \max
$$

\section{Завдання 4.}

Сформулюйте основні функціональні ознаки ознаки інформаційної складвої економічної безпеки підприємства

\begin{tabular}{|c|c|}
\hline Функціональна складова & Змістовні ознаки \\
\hline & \\
\hline
\end{tabular}

\section{Завдання 4.}

Визначте ефективність здійснених заходів по підтриманню економічної безпеки підприємства за екологічною складовою, якщо витрати на усунення негативних впливів становлять 1 тис.грн., розмір реалізованої шкоди 3,1 тис.грн., а отриманий ефект 1,6 тис.грн.

\section{Завдання 5.}

Визначте сукупний критерій економічної безпеки підприємства, якщо частковий функціональний критерій за фінансовою складовою становить 630 тис. грн., за екологічною 75,3 тис. грн., за інтелектуально - кадровою 5,69 тис. грн. При цьому, питома вага значущості часткових функціональних критеріїв економічної безпеки розподілилась відповідним чином - 0,45; 0,35; 0,15 .

\section{Тестові завдання для перевірки знань:}

\section{1. Сукупний критерій економічної безпеки визначається як:}

Відношення очікуваних збитків до відвернених;

Добуток очікуваних збитків та відверненої шкоди; 
Відношення реалізованих збитків та очікуваних;

Добуток часткових функціональних критеріїв та їх питомої ваги;

Добуток часткових функціональних критеріїв та коефіцієнтів ефективності.

2. Частковий функціональний критерій економічної безпеки розраховусться на основі:

Оцінки збитків кожної функціональної складової економічної безпеки підприємства і ефективності заходів щодо їх запобігання;

Оцінки рентабельності підприємства по кожній функціональній складовій;

Оцінки очікуваних збитків по кожній функціональній складовій;

Оцінки продуктивності по кожній функціональній складовій;

Оцінки відвернених коштів по кожній функціональній складовій.

3. Сукупний збиток при аналізі рівня економічної безпеки визначається як:

3.1 Різниця між очікуваним та реалізованим збитками;

3.2 Різниця між реалізованими та відверненими витратами;

3.3 Різниця між очікуваним та реалізованим збитком;

3.4 Сума відверненого та реалізованого збитку;

3.5 Сума між очікуваним та реалізованим збитком.

4. Карта функціонального аналізу економічної безпеки описує:

Рівень збитків по кожній функціональній складовій економічної безпеки підприємства;

Рівень збитків та ефекти, розділені на відповідні складові та вартість заходів по відверненню відповідних збитків;

Рівень економічного ефекту при відвертанні втрачених за відповідною складовою коштів;

Вартість утримання належного рівня економічної безпеки по кожній функціональній складовій;

Рівень ризиків та їх вартісний вимір по кожній функціональній складовій. 


\section{5. Сукупний критерій економічної безпеки:}

Повністю відбиває рівень економічної безпеки підприємства і $є$ незалежним від суб'єктного фактору;

Частково відбиває значення рівня економічної безпеки, але не залежить від суб'єктивних факторів;

Частково відбиває рівень економічної безпеки і залежить від суб'єктивних факторів;

Не належить до критеріїв експертного аналізу рівня економічної безпеки;

Відбиває лише суб’єктивні враження експертів про рівень очікуваних збитків.

\section{ПРАКТИЧНЕ ЗАНЯТТЯ 3}

\section{Tема: Основні напрями організації економічної безпеки на підприємстві}

Мета заняття: заняття є ознайомлення 3 організацією безпеки в залежності від розміру підприємства.

\section{План проведення заняття:}

1. Організація системи економічної безпеки підприємства

2. Інформаційно-аналітичне забезпечення системи управління економічною безпекою підприємства

3. Стратегічне та інноваційне забезпечення системи управління економічною безпекою підприємства

Ключові слова: система економічної безпеки, стратегічне забезпечення, інновачійне забезпечення, організачія системи.

Лimepamypa: 1 [p.18]; 10; 7[p.4].

\section{Питання для дискусії}

1. Основні принципи побудови системи економічної безпеки підприємства.

2. Розкрийте основні завдання системи економічної безпеки підприємства.

3. Наведіть основні елементи системи економічної безпеки підприємства.

4. Розкрийте сутність поняття «податкова безпека». 
5. Дайте характеристику системі економічної безпеки підприємства.

6. Основні етапи моніторингу рівня економічної безпеки підприємства.

7. Основні властивості інформації.

8. Принципи створення раціонального потоку інформації про економічну безпеку підприємства.

9. Інтеграція підходів та методів до оцінки економічної безпеки підприємства.

10. Особливості використання факторного, кластерного аналізу та побудови багатошарового нейронного персептрона при оцінюванні економічної безпеки підприємства.

11. Основні відмінності використання статичних та динамічних економікоматематичних моделей для оцінювання економічної безпеки підприємства.

12. Стратегічне та інноваційне забезпечення системи управління економічною безпекою підприємства.

\section{Завдання 1}

Виділіть основні відмінності між показниками та індикаторами економічної безпеки підприємства.

\section{Завдання 2.}

Визначте основні відмінності при використанні методів експертного оцінювання та економіко-математичних методів при проведенні оцінки рівня економічної безпеки підприємства.

\section{Завдання 3.}

Обгрунтуйте, які методи оцінки економічної безпеки необхідно використовувати на макро-, мезо- та мікро- рівнях економіки?

\section{Завдання 4.}

Необхідно провести оцінку рівня економічної безпеки підприємства за допомгою графічного способу за нормативами.

Вибір індикаторів для оцінки рівня економічної безпеки ВАТ «Світло Шахтаря» проводився на основі ресурсно-функціонального підходу. Нормативні й критичні значення більшості індикаторів рівня економічної 
безпеки підприємства були встановлені експертним шляхом.

Для графічного представлення показників оцінки рівня економічної безпеки підприємства необхідно провести їх нормалізацію. Для визначення областей предкритичного й критичного стану економічної безпеки підприємства, нормалізуємо критичні значення, а також значення верхньої й нижньої межі критичних значень (дані в табл.)

Таблиия

\section{Показники діяльності підприємства ВАТ «Світло Шахтаря» на кінець 2010 р. (після проведення нормалізації)}

\begin{tabular}{|c|c|c|c|c|c|c|}
\hline Назва показника & 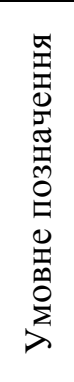 & 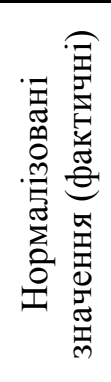 & 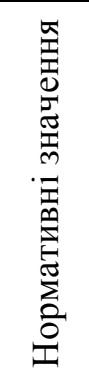 & 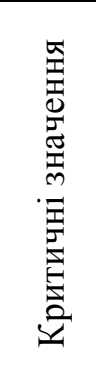 & 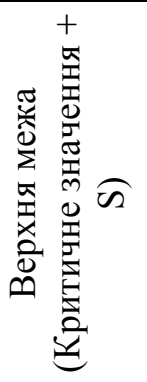 & 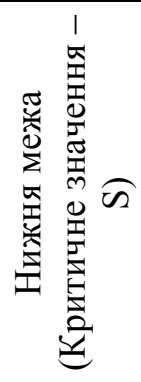 \\
\hline $\begin{array}{l}\text { Питома вага працівників, що } \\
\text { підвищили кваліфікацію в загальній } \\
\text { чисельності }\end{array}$ & $\mathrm{P} 1$ & 0,97 & 1,00 & 0,25 & 0,30 & 0,20 \\
\hline $\begin{array}{l}\text { Коефіцієнти придатності основних } \\
\text { засобів }\end{array}$ & $\mathrm{P} 2$ & 0,67 & 1,00 & 0,43 & 0,51 & 0,34 \\
\hline Коефіцієнт стійкості фінансування & $\mathrm{P} 3$ & 1,00 & 1,00 & 0,67 & 0,80 & 0,53 \\
\hline $\begin{array}{l}\text { Співвідношення темпів зростання } \\
\text { випуску готової продукції й } \\
\text { операційних витрат }\end{array}$ & P4 & 0,77 & 1,00 & 0,67 & 0,80 & 0,53 \\
\hline Коефіцієнт швидкої ліквідності & P5 & 1,00 & 1,00 & 0,60 & 0,72 & 0,48 \\
\hline $\begin{array}{l}\text { Коефіцієнт забезпеченості власними } \\
\text { обіговими коштами }\end{array}$ & P6 & 1,00 & 1,00 & 0,50 & 0,60 & 0,40 \\
\hline Рентабельність чистого прибутку & $\mathrm{P} 7$ & 0,57 & 1,00 & 0,50 & 0,60 & 0,40 \\
\hline $\begin{array}{l}\text { Співвідношення темпів зростання } \\
\text { продуктивності праці й заробітної } \\
\text { плати }\end{array}$ & $\mathrm{P} 8$ & 0,74 & 1,00 & 0,67 & 0,80 & 0,53 \\
\hline Показник рентабельності продажів & P9 & 1,00 & 1,00 & 0,50 & 0,60 & 0,40 \\
\hline
\end{tabular}


Мета заняття: засвоїті основні принципи організації служби безпеки на підприємстві та іiї взаємодії з іншими пірозділами.

\section{План проведення заняття:}

1. Служба безпеки на підприємстві та ії функції по підтриманню належного рівня економічної безпеки підприємства

2. Діяльність служби безпеки в правовому аспекті

2.1 Підпорядкованість служби безпеки

3. Коордінаційна роль служби безпеки в забезпечені економічної безпеки підприємства

3.1 Взаємодія служби безпеки з підрозділами підприємтсва

4. Шляхи вдосконалення служби безпеки на підприємтсві

4.1 Розширення сфери діяльності служби безпеки.

4.2 Поглиблення впливу служби безпеки на підприємтсво.

4.3 Підтримка покращення взаємодії з підрозділами служби безпеки

Ключові слова: служба безпекі, принциии, функиії, фукиіональні обов'язки, координація, функиіональна взаємодія.

Лimepamypa: 2 [p.2]

\section{Питання для дискусії}

1. Що вирозумієте під охоронною діяльністю?

2. Основні завдання державної служби охорони.

3. Права державної служби охорони.

4. Обов'язки працівників державної служби охорони під час несення служби.

5. Права державної служби охорони.

6. Перелічіть об'єкти, які підлягають обов'язковій охороні підрозділами державної служби охорони при МВС України.

7. Що ви розумієте під термінами?

а) охорона майна;

б) охорона громадян;

в) охоронна діяльність; 
г) суб'єкти охоронної діяльності;

г) об'єкти охорони;

д) персонал охорони.

8. Хто належить до персоналу охорони суб'єктів охоронної діяльності?

9. Які заходи можуть здійснюватися персоналом охорони безпосередньо?

10. Що повинен забезпечити суб'єкт охоронної діяльності, який надає послуги згідно з отриманою ліцензією?

11. Обов 'язки суб'єкта охоронної діяльності, який надає послуги згідно 3 отриманою ліцензією.

12. Які норми кримінального кодексу, кодексу про адміністративні правопорушення, Закону «Про міліцію», нормативно-правові акти повинен знати персонал охорони?

13. Що забороняється під час здійснення охоронної діяльності суб'єкта охоронної діяльності?

14. Які громадяни не можуть залучатися до охоронної діяльності?

15. Права працівників органу контролю, які здійснюють перевірку діяльності ліцензіата.

16. Що мають безпосередньо на підприємстві перевіряти працівники органу контролю при проведенні перевірки?

17. Що є підставами для анулювання ліцензії?

18. Що ви розумієте під детективною діяльністю?

19. Які послуги виконує детектив?

20. Що собою являє детективна організація?

21. Права суб’єктів детективної діяльності в межах наданої їм компетенції.

22.Обов'язки суб'єктів детективної діяльності в межах наданої їм компетенції.

23. Які відомості повинні міститися у заяві на видачу ліцензії на здійснення детективної діяльності?

24. За якими підставами може бути припинена детективна діяльність?

\section{Завдання 1.}


Складіть функціональну карту служби безпеки на підприємстві в залежності від виду діяльності та обсягів функціонування підприємтсва.

\section{Завдання 2.}

Визначте складові організаційної структури служби безпеки на підприємтсві

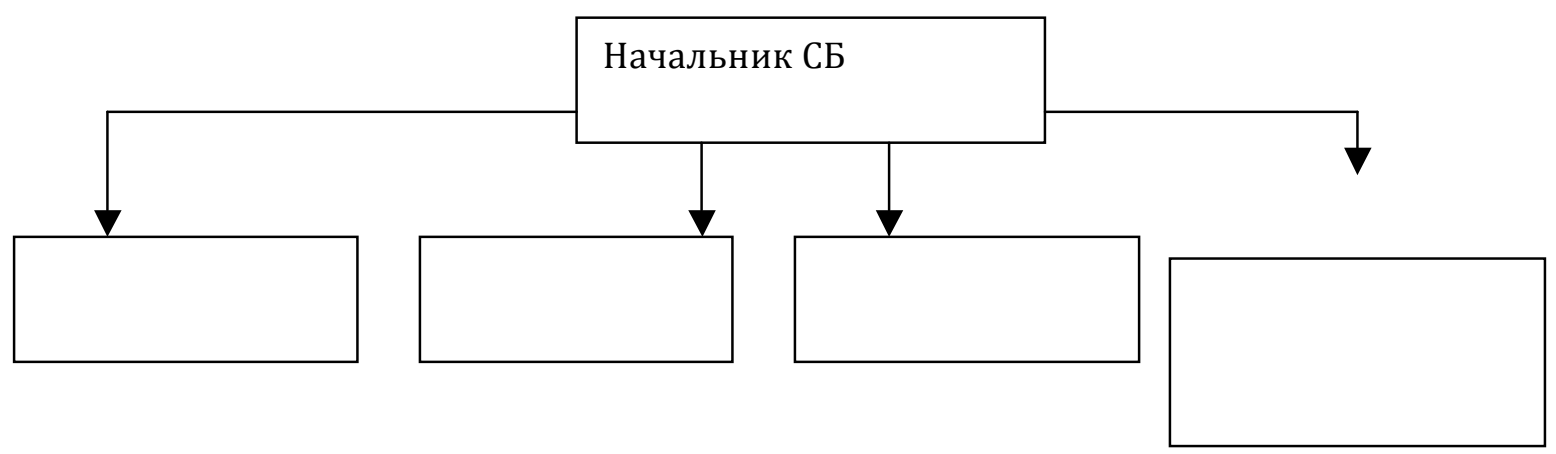

Завдання 3.

Вивчивши попередні 2 теми студенти повинні дати правильні відповіді на питання, які закони регулюють діяльність служби безпеки підприємств, відмітивши їх галочкою.

\begin{tabular}{|l|l|l|}
\hline Найменування закону Україну & & \\
\hline $\begin{array}{l}\text { Про засади державної регуляторної політики у сфері } \\
\text { господарської діяльності }\end{array}$ & & \\
\hline Про служби безпеки суб’єктів господарювання & & \\
\hline Про міліцію & & \\
\hline Про оперативно-розшукову діяльність & \\
\hline Про банки і банківську діяльність & \\
\hline
\end{tabular}

\section{Завдання 4.}

Складіть опорно-структурну схему «Реальні та потенційні загрози бізнесу» за таким зразком:

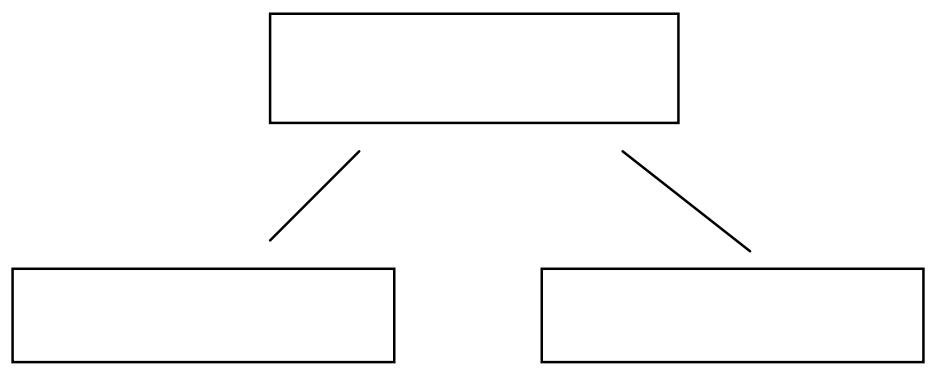




\section{Тестові завдання для перевірки знань:}

\section{1. Реальні та потенційні загрози бізнесу:}

1.1 зростання кредитних ризиків;

1.2 фінансові кризи;

1.3 зниження інвестиційної активності;

1.4 критичний стан основних виробничих фондів підприємства;

1.5 усі відповіді правильні.

\section{2. Реальними та потенційними загрозами бізнесу можуть бути:}

2.1 нестабільність у правовому регулюванні відносин у сфері фіскальної політики держави;

2.2 силова система економічної безпеки;

2.3 промислове шпигунство;

2.4 рейдерство;

2.5 інформаційна система економічної безпеки.

3. Система економічної безпеки підприємства включас такі складові:

2.1 фінансову;

2.2 кредитні ризики;

2.3 силову;

2.4 інформаційну;

2.5 зниження інвестиційної активності.

4. Ризики підприємницької діяльності за сферами виявлення можна класифікувати так:

4.1 економічний;

4.2 політичний;

4.3 соціальний;

4.4 екологічний;

4.5 рейдерство.

5. До основних завдань служби безпеки відносять:

5.1 проведення моніторингу загроз і небезпек; 
5.2 вироблення механізму управління загрозами і небезпеками;

5.3 ведення реєстру надійних партнерів;

5.4 пошук втраченого майна;

5.5 організація взаємодії з правоохоронними органами.

6. Оперативно-розшукова діяльність здійснюється:

6.1 МВС України;

6.2 СБУ;

6.3 Службою безпеки суб'єкта господарювання;

6.4 детективною організацією;

6.5 Службою зовнішньої розвідки України.

7. Служба безпеки підприємства зобов'язана:

7.1 взаємодіяти з правоохоронними органами;

7.2 забезпечувати безпеку громадян;

7.3 проводити профілактичну роботу серед персоналу об'єкта;

7.4 охороняти майно об'єкта;

7.5 всі відповіді правильні.

8. Правова служба безпеки підприсмства:

8.1 подавати запити до правоохоронних органів;

8.2 мати безоплатний доступ до інформаційних баз органів статистики, податкової та інших;

8.3 створювати детективні підрозділи;

8.4 створювати інформаційно-аналітичні бази даних;

8.5 проводити огляд поклажі, багажу та огляд персоналу об'єкта 3 метою забезпечення об'єкта.

\section{9. Об'єктом підвищеної небезпеки с об'скт, на якому:}

9.1 використовуються;

9.2 виготовляються;

9.3 перероблюються;

9.4 транспортуються небезпечні речовини, що перевищують нормативно встановлені порохові маси; 
9.5 усі відповіді правильні.

\section{0. Суб'скт об’єкта підвищеної небезпеки зобов`язаний:}

10.1 вживати заходів, спрямованих на запобігання аваріям;

10.2 повідомляти про аварію;

10.3 забезпечувати як експлуатацію об'єктів із додержанням міжнародно можливого ризику;

10.4 виконувати вимоги нормативно-правових актів, що регулюють діяльність об'єктів підвищеної небезпеки;

10.5 усі відповіді правильні.

\section{1. Загальні функції служби безпеки підприсмства:}

11.1організація і забезпечення пропускного режиму;

11.2 участь у розробленні ПВТР підприємства;

11.3 виявлення i перекриття можливих каналів витоку таємної та конфіденційної інформації;

11.4 організація та проведення службових розслідувань;

11.5 підтримка контактів із правоохоронними органами.

\section{2. Основні завдання Державної служби охорони:}

12.1 вимагання від працівників суб'єктів господарювання, що охороняються, додержання встановленого пропускного режиму;

12.2 проводити у встановленому порядку особистий огляд громадян, які перебувають на території об'єкта;

12.3 здійснювати за договорами заходи щодо охорони особливо важливих об'єктів;

12.4 розробляти основні вимоги до захисту об’єктів та громадян від злочинних посягань.

\section{3. Права працівників державної служби охорони під час виконання службових обов'язків :}

13.1 доставляти в службові приміщення охорону для встановлення особи та складати протоколи про правопорушення на осіб, які вчинили правопорушення; 
13.2 проводити огляд транспортних засобів, які від’їжджають за територію об'єкта;

13.3 захищати об'єкти охорони від злочинних посягань;

13.4 взаємодіяти 3 органами внутрішніх справ щодо припинення правопорушень у місцях несення служби.

14. Обов'язки працівників Державної служби охорони під час несення служби:

14.1 зберігати таємницю;

14.2 взаємодіяти 3 органами внутрішніх справ щодо припинення правопорушень у місцях несення служби;

14.3 застосовувати технічні засоби охоронного призначення;

14.4 вимагати від працівників об'єктів, що охороняються, додержуватися встановленого пропускного режиму.

15. До персоналу охорони суб’сктів охоронної діяльності належать:

15.1 керівники суб'єктів господарювання;

15.2 члени сімей керівників суб’єктів господарювання;

15.3 охоронники та члени їх сімей;

15.4 охоронці - працівники суб'єктів охоронної діяльності.

16. Персоналом охорони можуть здійснюватися безпосередньо такі заходи охорони:

16.1 контроль за проходженням на об'єкт охорони;

16.2 застосування пропускного режиму;

16.3 використання технічних засобів охоронного призначення;

16.4 використання службових собак.

17. 3 метою організації та під час здійснення охоронної діяльності заборонясться:

17.1 придбавати та використовувати для виконання функцій з організації та здійснення заходів охорони рухомого та нерухомого майна, що може використовуватися правоохоронними органами; 
17.2 здійснювати за цивільно-правовими договорами заходи охорони майна без наявності відповідних документів, які підтверджують повноваження замовника охоронних послуг щодо володіння цим майном;

17.3 протидіяти представникам правоохоронних органів під час виконання покладених на них завдань із забезпечення правопорядку;

17.4 усі відповіді правильні.

18. До охоронної діяльності не можуть залучатися такі категорії громадян:

18.1 які не досягли повноліття;

18.2 визнані судом недієздатними;

18.3 які ухиляються від призову на дійсну військову службу;

18.4 особи, які не зареєстровані за місцем проживання.

19. Позапланові перевірки здійснюються органами контролю за таких підстав:

19.1 надходження до органу контролю в письмовій формі повідомлення про порушення ліцензіатом ліцензійних умов;

19.2 з метою перевірки виконання розпорядження про усунення порушень ліцензійних умов;

19.3 за власною ініціативою працівника контролюючих органів.

20. Детектив виконус такі функції:

20.1 збір відомостей з цивільних справ на договірній основі;

20.2 проведення оперативно-розшукових заходів;

20.3 збір інформації для ділових переговорів;

20.4 встановлення авторів і відправників анонімних листів.

\section{1. Суб̆ скти детективної діяльності зобов'язані:}

21.1 дотримуватися вимог законодавства;

21.2 професійно виконувати умови договорів;

21.3 не розголошувати отриману інформацію;

21.4 опитувати громадян і посадових осіб.

22. Детективна діяльність може бути припинена за такими підставами: 
22.1 за власною ініціативою суб'єкта детективної діяльності;

22.2 у зв'язку із закінченням терміну дії ліцензії;

22.3 на вимогу місцевих органів державної виконавчої влади;

22.4 за рішенням суду.

\section{ПРАКТИЧНЕ ЗАНЯТТЯ 5}

Тема: Організація захисту комерційної таємниці на підприсмстві

Мета заняття: ознайомлення 3 організацією на підприємстві режимів та документального оформлення щодо встановлення комерційної таємниці.

\section{План проведення заняття:}

1. Характеристика різновидів нформації.

2. Види інформація з обмеженим режимом доступу

3. Методи виділення та способи захисту комерційної таємниці

4. Організаційні заходи на підприємстві щодо встановлення комерційної таємниці

Ключові слова: інформачія, конфідениійна інформаџія, комериійна таємниия, режим доступу, режим захисту

Лimepamypa: 1 [р.18]; 10; 12 [р.1]; 5 [р.2]; 7 [р.4]

\section{Питання для дискусії}

1. Наведіть визначення інформації.

2. Ознаки інформації.

3. Основні види інформації.

4. Охарактеризуйте такі види інформації:

а) статистичну;

б) адміністративну;

в) масову;

г) інформацію державних органів та органів місцевого самоврядування;

д) правову інформацію;

є) інформацію про осіб;

ж) соціологічну інформацію; 
д) інформацію про осіб;

е) соціологічну інформацію.

5. Які є підстави виникнення права власності на інформацію?

6. Що ви розумієте під інформацією з обмеженим доступом?

7. Охарактеризуйте такі види інформації:

а) конфіденційну;

б) таємну.

8. Перелічіть види таємної інформації.

9. Охарактеризуйте службову, професійну, державну, банківську таємниці.

\section{Завдання 1.}

Узагальніть основні складові комерційної інформації за фунціональноуправлінською ознакою

\begin{tabular}{|l|l|}
\hline Складові комерційної інформації & Зміст складових \\
\hline & \\
\hline
\end{tabular}

\section{Завдання 2.}

Узагальніть зміст банківської таємниці та визначте основні відомості, що їі становлять

\begin{tabular}{|l|l|}
\hline Зміст банківської таємнці & Відомості, що становлять банківську таємницю \\
\hline & \\
\hline
\end{tabular}

Завдання 3.

Складіть опорно-структурну схему «основні види інформації» за таким зразком:

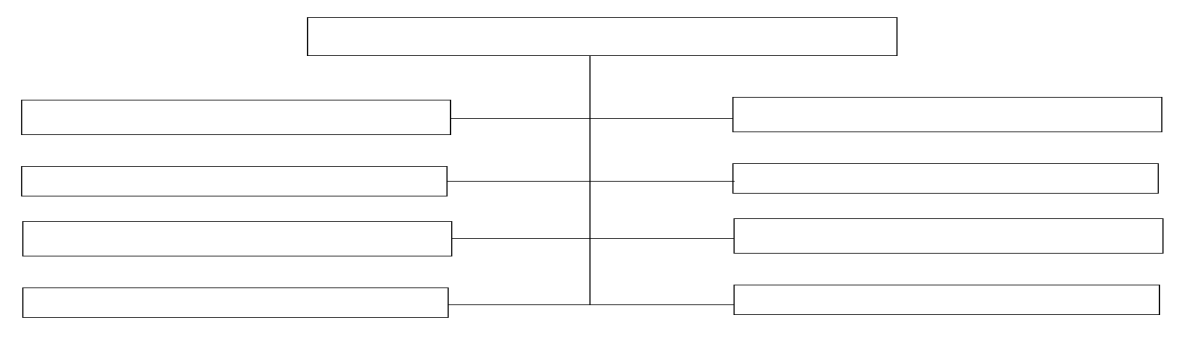

Завдання 4.

Охарактеризуйте статистичну, адміністративну інформації. В чому полягає їх відмінність? 


\section{Завдання 5.}

Підготуйте реферати на тему:

а) поняття, правові ознаки та види інформації;

б) поняття та види інформації з обмеженим доступом;

\section{Тестові завдання для перевірки знань:}

1. Таємна інформація це:

Інформація, що містить відомості, які встановлюють державну та іншу передбачену законом таємницю, розголошення якої завдає шкоди особі, суспільству і державі;

Інформація, що містить від ості, які встановлюють лише державну таємницю;

Відомості, які знаходяться у користуванні або розпорядженні окремих фізичних чи юридичних осіб і поширюються за їх бажанням;

Відомості, які можуть носити будь-яку інформацію професійного, ділового характеру;

Інформація, що може нанести шкоду суспільству та економічні безпеці держави.

2. Конфіденційна інформація - :

Інформація, що містить відомості, які встановлюють державну та іншу передбачену законом таємницю, розголошення якої завдає шкоди особі, суспільству і державі;

Інформація, що містить від ості, які встановлюють лише державну таємницю;

Відомості, які знаходяться у користуванні або розпорядженні окремих фізичних чи юридичних осіб і поширюються за їх бажанням;

Відомості, які можуть носити будь-яку інформацію професійного, ділового характеру;

Інформація, що може нанести шкоду суспільству та економічні безпеці держави. 
3. Комерційна таємниця -:

Відомості, які можуть бути віднесені до державної таємниці;

Відомості, пов'язані з виробництвом, технологічною інформацією, управлінням, фінансами та іншою діяльністю підприємства, що не $є$ державними таємницями;

Відомості, які безпосередньо не пов'язані з виробничою діяльністю підприємства, але можуть нанести йому шкоди;

Відомості про конкурентні переваги підприємства;

Інформація, якою володіє відділ маркетингу підприємства.

4. Перелік відомостей, що належить до комерційної таємниці затверджує:

Відповідний орган державного регулювання;

Начальник служби безпеки підприємства;

Керівник підприємства;

Начальник відділу маркетингу;

Головний технолог підприємства.

5. Який із відділ не належить до організаційної структури служби безпеки підприємства, що займається охороною комерційної таємниці:

Відділ режиму та охорони, в складі сектору режиму та сектору охорони;

Спеціального відділу в складі сектору обробки секретної документації;

Інженерно-технічна група;

Група безпеки зовнішньої діяльності;

Контрольно-ревізійний відділ.

\section{ПРАКТИЧНЕ ЗАНЯТТЯ 6}

Тема: Промислова розвідка та промисловий шпіонаж

Мета заняття: визначення впливів промислової розвідки на розвиток підприємства та ознайомлення із сучасними методами промислового шпіонажу, які властиві Україні. 


\section{План проведення заняття:}

1.Вплив промислової розвідки на розвиток підприємства

2.Сучасні методи промислового шпіонажу, що властиві Україні

3. Еволюція виникнення та розвитку промислового шпіонажу.

4. Приклади розвитку компаній, що використовувалі промисловий шпіонаж та розвідку.

Ключові слова: промислова розвідка, шпигунство, легальні методи, нелегальні методи, службові розслідування.

Лimepamypa: 11; 4; 6; 3.

\section{Питання для дискусії}

1. Які завдання виконує конкурентна розвідка?

2. У яких випадках конкурентна розвідка може відігравати життєво важливу роль у діяльності підприємства?

3. Охарактеризуйте етапи розвідувального циклу обробки інформації.

4. Яким чином можна створити конкурентну розвідку на підприємстві?

5. Основні завдання інформаційно-аналітичного підрозділу підприємства.

6. 3 яких напрямків конкурентна розвідка повинна надавати керівництву підприємства розвідувальну інформацію?

7. Які є типові помилки у побудові системи інформаційно-аналітичного забезпечення підприємств?

\section{Завдання 1.}

Скласти опорно-структурну схему «Завдання конкурентної розвідки» за таким зразком: 


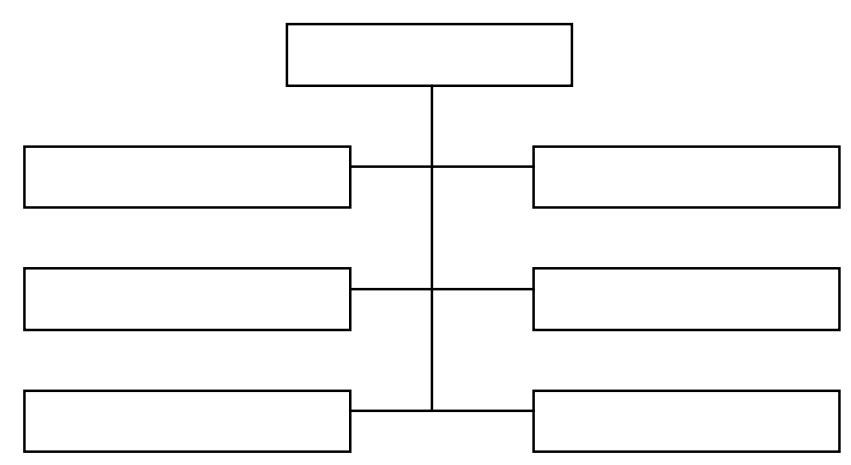

Завдання 2.

Скласти опорно-структурну схему «Типові помилки у побудові системи інформаційно аналітичного забезпечення підприємств» за таким зразком

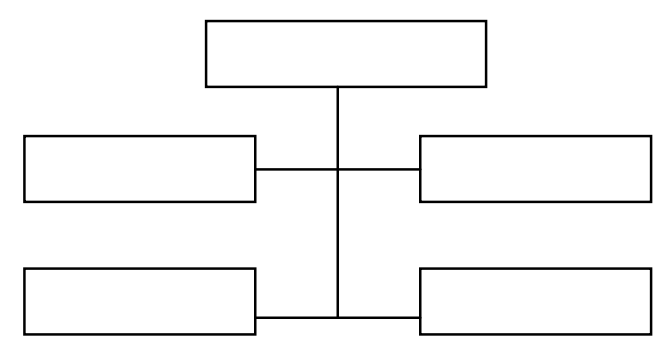

Завдання 3.

Порівняйте конкурентну розвідку та промисловий шпіонаж як прояв загрози конкурентних дій економічні безпеці підприємства

\begin{tabular}{|l|l|}
\hline Конкурентна розвідка & Промисловий шпіонаж \\
\hline & \\
\hline
\end{tabular}

\section{Завдання 4.}

Визначте яким чином здійснюється економічна оцінка втрати комерційної таємниці підприємтсва.

\section{Завдання 5.}

Охарактеризуйте основні проблеми захисту: підприємницької діяльності, інформації, комерційної таємниці, фізичних осіб, від радіоелектронної розвідки. 


\section{ПРАКТИЧНЕ ЗАНЯТТЯ 7}

\section{Тема: Економічні злочини, які впливають на стан економічної безпеки підприсмництва}

Мета: визначення ознак злочинів, які впливають на стан економічної безпеки підприємства та їх законодавче регулювання. проведення модульної контрольної роботи за темами кредитного модуля.

\section{План проведення заняття:}

1. Визначення ознак злочинів, які впливають на стан економічної безпеки підприємства.

2. Основні види економічних злочинів та їх законодавче регулювання.

3.Проведення усного опитування усного опитування по темам 1.1-1.4

Ключові слова: економічний злочин, злочин проти власності, злочини в господарські діяльності, фіктивне підприємництво, фіктивне банкруцтво, службові злочина, крадіжка, грабіж, шахрайство, розбій.

Лimepamypa: 1 [p.18]; 10; 7[p.4].

\section{Питання для дискусії}

1. Поняття, загальна характеристика та види злочинів у сфері господарської діяльності.

2. Критерії визначення розмірів отриманого доходу, заподіяної шкоди та інших наслідків у злочинах у сфері господарської діяльності.

3. Характеристика предметів та ознак об’єктивної сторони злочинів, що посягають на встановлений порядок виготовлення i використання документів у господарській діяльності (статті 199, 200, 215, 216, 223 і 224 КК України).

4. Аналіз складу злочину «контрабанда».

5. Аналіз складу злочину «порушення порядку зайняття господарською та банківською діяльністю». 
6. Особливості ознак об'єктивної сторони спеціальних видів порушення порядку зайняття господарською діяльністю (статті 203, 203 ${ }^{1}$, 204, 213 і 214 КК України).

7. Аналіз складу злочину «фіктивне підприємництво».

8. Аналіз складу злочину «легалізація (відмивання) доходів, одержаних злочинним шляхом».

9. Аналіз складу злочину «ухилення від сплати податків, зборів, інших обов'язкових платежів».

10. Особливості предмета злочинів «незаконне відкриття або використання за межами України валютних рахунків» та «приховування валютної виручки».

11. Характеристика об’єктивної сторони злочинів, що посягають на встановлений порядок формування та витрачання бюджетних коштів.

12. Особливості об'єктивної сторони злочинів, пов'язаних 3 банкрутством (статті 218, 219, 220 і 221 КК України).

13. Відмежування шахрайства $з$ фінансовими ресурсами від злочинів проти власності.

14. Аналіз складу злочину «обман покупців та замовників».

15. Особливості предмета та ознак об'єктивної сторони випуску недоброякісної продукції.

16. Поняття комерційної таємниці як предмета злочинів, передбачених статтями 231 та 232 КК України.

17. Характеристика об'єктивної сторони злочинів, що посягають на свободу господарської діяльності (статті 206, 228 КК України).

18. Аналіз складу злочину «незаконна приватизація державного, комунального майна».

\section{Завдання 1.}

Учень художнього технікуму Зоренко намалював два банківських білети вартістю 100 грн. кожний. При спробі збути один з них його було затримано. 
Варіант 1. Не сказавши про підробку, Зоренко дав одну купюру Ковалю в оплату боргу. Підробку було викрито, коли Коваль подав купюру до каси магазину.

Варіант 2. Зоренко виготовив банківський білет, щоб показати товаришам свою художню майстерність.

\section{Завдання 2.}

Чепас 3 допомогою виготовленого ним шрифту підробляв номери на білетах лотореї «Лото-забава», по яких одержував виграші - всього в сумі 10 тис. грн.

Варіант 1. Чепас одержав виграші на цю суму за підробленими ним казначейськими зобов'язаннями.

Варіант 2. Він одержав ці гроші за підробленим акредитивом.

\section{Завдання 3.}

Рокитянський купив у Львові діамант без оправи, який таємно вивіз до Німеччини, де продав його за 15 тис. євро.

Дайте кримінально-правову оцінку дій Рокитянського.

\section{Завдання 4.}

Машиніст Малінін у подвійній підлозі тепловоза кілька разів провозив 3-за кордону диски для лазерних систем зчитування із записами порнографічного характеру, які продавав потім своїм знайомим та передавав на реалізацію приватному підприємцю Акулову. Усього Малініним було контрабандно ввезено в Україну дисків на суму 80 тис. грн., 3 них Акулов реалізував їх на суму 21 тис. грн.

\section{Завдання 5.}

При митному огляді прибулого 3-за кордону в Одесу риболовецького траулера було виявлено 1237 головних хусток на суму 60 тис. грн., а також помпову рушницю вартістю 6 тис. грн. Їх привіз, сховавши в машинному відділенні, матрос Краковний, маючи намір продати на ринках Одеси.

Чи $є$ в діях Краковного ознаки (i які саме) складу злочину «контрабанда»? 


\section{Завдання 6.}

Під час митного огляду в Царенка в мішечку, що висів на шиї, було виявлено золоті вироби (каблучки, персні тощо) на суму 87200 грн.

Варіант 1. Вироби містились у гніздах, видовбаних у підборах черевиків.

Варіант 2. Вироби містились у валізі Царенка.

\section{Завдання 7.}

Іноземець Фрідлянд, повертаючись із туристичної подорожі Україною, намагався незаконно вивезти за кордон дві старовинні ікони на суму 16 тис. грн., поклавши їх у валізу з подвійним дном.

\section{Завдання 8.}

Керівник філії банку Власов від окремих громадян приймав начебто на депозит великі суми іноземної валюти з виплатою відсотків, удвічі більших, ніж за депозитними договорами виплачував банк. Договори оформлялися від імені банку, на них проставлялась печатка філії банку. Одержання грошей ніякими документами, крім договорів, не підтверджувалося, депозитні рахунки не відкривались. Отримані кошти Власов надавав у кредит тіньовим структурам під більш високі відсотки, ніж виплачував «вкладникам». На кредитних договорах також проставлялася печатка банку. Усього від своєї діяльності Власов протягом двох років одержав дохід у сумі 400 тис. доларів США. Громадяни, які «вкладали» кошти на депозитні рахунки, і громадяни, які брали кошти в кредит, усвідомлювали, що кошти через касу філії банку не оприбутковувалися.

Дайте кримінально-правову оцінку діям Власова.

\section{Завдання 9.}

Гришин і Федоров за вкраденими паспортами на ім'я їх власників зареєстрували кілька приватних підприємств, через які здійснювали незаконні конвертаційні операції. 3 легально діючими суб’єктами господарської діяльності від імені створених підприємств укладались удавані угоди на поставки товарів чи надання послуг, за якими такі суб'єкти 
перераховували безготівкові кошти на рахунки створених приватних підприємств, a взамін їх керівники отримували готівкові кошти в національній чи іноземній валюті. Безготівкові кошти за удаваними угодами перераховувалися на рахунки інших суб'єктів господарської діяльності, від яких Гришин i Федоров отримували готівкові кошти, отримані цими суб'єктами від незаконної реалізації контрабандно ввезених чи виготовлених підпільно товарів.

Дайте кримінально-правову оцінку дій Гришина, Федорова та їх клієнтів.

\section{Завдання 10.}

Без державної реєстрації як суб’єктів підприємницької діяльності зубні техніки медичних установ Швець і Ніколаєв за змовою між собою, а також самостійно систематично протягом чотирьох років за місцем своєї роботи виготовляли і там же або на квартирах клієнтів ставили за плату зубні коронки. Разом вони виготовили 428 зубних коронок (в тому числі 346 iз золота клієнтів). Швець виготовив 280 коронок (у тому числі із золота клієнтів 220), а Ніколаєв - 148 (всі з золота клієнтів). Вартість кожної коронки становила 750 грн.

Дайте кримінально-правову оцінку дій Швеця і Ніколаєва.

\section{Завдання 11.}

Квітко та Дідовець вирішили проявити підприємницьку ініціативу i досягти добробуту за рахунок придбання товарів за кордоном і вигідного збуту їх в Україні. Вони кілька разів літали туристичними авіарейсами в АбуДабі. Там купували відеоапа-ратуру, предмети одягу, галантерею, які продавали на речовому ринку. Один політ приносив кожній з компаньйонок прибуток у розмірі 1500-2500 грн. Усього від продажу зазначених товарів Квітко і Дідовець спільно отримали доход у сумі 62 тис. грн.

\section{Завдання 12.}

Художник-оформлювач Горбулько у вільний від роботи на комбінаті монументально-декоративного мистецтва час удома займався на замовлення 
клієнтів виготовленням 3 їхніх матеріалів виробів із золота, срібла, а також виготовленням і ремонтом виробів із застосуванням топазів, александритів, перлів і бурштину. Протягом року він одержав від своїх клієнтів 240 тис. грн. Свою діяльність Горбулько не реєстрував і податків не сплачував.

\section{Завдання 13.}

Карпенко з плодів свого саду та плодів, куплених у сусідів-садоводів, виробляв вино, яке продавав за цінами, що не перевищували роздрібних цін на аналогічний товар. Він же перевозив за плату пасажирів на власному автомобілі, який придбав за гроші, одержані від продажу вина. Спеціального дозволу на заняття такими видами діяльності Карпенко не брав. Усього Карпенком було реалізовано вина на 49 тис. грн., а від перевезення пасажирів він протягом року одержав 17 тис. грн.

\section{Завдання 14.}

Глось у власному гаражі встановив обладнання для виробництва фальсифікованої горілки шляхом розбавлення спирту етилового водопровідною водою. «Допомагали» Глосю найняті ним громадяни Кошель і Литвин, яким він за кожну пляшку виготовленої горілки платив по 20 коп. Скляні пляшки Глось купував у пункті приймання склотари. На пляшки наклеювались етикетки та контретикетки відомих виробників горілчаних виробів, на яких містилися зображення їх торговельних марок, які на замовлення Глося незаконно виготовляв працівник поліграфічного підприємства Чобіт, а також справжні марки акцизного збору 3 голографічними захисними елементами, які Глось купував у начальника цеху лікеро-горілчаного заводу Кравця.

Спирт Глось купував в Оськіна, який його контрабандно завозив 3 Республіки Молдова. Реалізовувались виготовлені горілчані вироби через кіоски приватних підприємців Ігумнова та Шкіля на дрібнооптовому ринку, які мали ліцензії на реалізацію алкогольних напоїв.

Усього за 3 місяці було виготовлено 60 тис. пляшок горілки, які Глось передав для реалізації Ігумнову та Шкілю за 240 тис. грн. Реалізація 
горілчаних виробів, виготовлених Глосьом, Ігум-новим i Шкілем здійснювалася без відображення у бухгалтерському обліку.

Якою має бути кримінально-правова оцінка дій усіх цих осіб?

\section{Завдання 15.}

Сторожук у себе вдома обладнав майстерню 3 ремонту радіотелевізійної апаратури, в якій тривалий час надавав послуги клієнтам за договірними цінами. Пізніше він почав також широко практикувати записи пісень у виконанні популярних зарубіжних i вітчизняних співаків (не питаючи в них дозволу): чисті касети купував у магазинах, а, записавши 3 допомогою наявної у нього апаратури пісні, продавав касети на речовому ринку.

Чи є дії Сторожука кримінально караними?

\section{ПРАКТИЧНЕ ЗАНЯТТЯ 8}

Тема: Технологічні та функціональні дії щодо захисту від погроз економічної безпеки

Мета заняття: ознайомлення із технічним забезпечення систем захисту економічної безпеки.

\section{План проведення заняття:}

1. Методи підбору персоналу, що відповідає системі захисту економічної безпеки підприємства.

2. Технічне забезпечення систем захисту економічної безпеки.

Ключові слова: технічне забезпечення, стратегічне планування, прогнозування економічної діяльності підприємтсва

Лimepamypa: 1 [p.18]; 10; 7[p.4].

\section{Питання для дискусії}

1. За допомогою яких показників можна проаналізувати рівень забезпечення техніко-технологічної безпеки підприємства?

2. Які фактори $\epsilon$ небезпечними 3 боку виробничого середовища на підприємствах промисловості? 
3. Які дії використовує підприємство для мінімізації виробничих ризиків?

4. Розкрийте сутність системи управління охороною здоров'я і безпекою персоналу.

5. Яке місце займає кадрова безпека в структурі соціально- економічної безпеки підприємства?

6. Які ознаки правопорушень в поведінці співробітників свідчать про можливі злочини?

7. Яку звітність підприємства можна використати для визначення показників оцінки кадрової безпеки?

8. Які дії негативно впливають на інтелектуальну складову СЕБ?

9. Які існують загрози інтелектуальній безпеціна підприємствах

10. Яка кримінальна відповідальність за порушення прав інтелектуальної власності передбачається чинним законодавством?

12. Які особисті якості керівника в контексті забезпечення кадрової безпеки підприємства?

\section{Завдання 1.}

Наведіть основні положення Закону України «Про захист персональних даних», що стосуються кадрової безпеки

\section{Завдання 2.}

Наведіть порядковість суб’єктів скоєння економічних злочинів. Перечислить види порушень при недотриманні кадрової безпеки.

\section{Завдання 3.}

Розкрийте складові кадрової безпеки підприємства. Від яких чинників залежить ефективність та продуктивність роботи персоналу?

\section{Завдання 4.}

Наведіть етапи забезпечення техніко-технологічної безпеки підприємства

\section{ПРАКТИЧНЕ ЗАНЯТТЯ 9}

Тема: Принципи та етапи забезпечення економічної безпеки підприємства 
Мета: формування практичних навичок щодо мінімізації витрат на створення механізму економічної безпеки та виявлення неспівпадіння у системі використання ресурсів.

\section{План проведення заняття:}

1. Забезпечення мінімізації витрат підприємства відповідно до механізму забезпечення економічної безпеки підприємства

2. Інструменти виявлення неспівпадіння використання ресурсів підприємства, що обумовлені видом ресурсів.

3. Матриця розподілу ресурсів підприємства.

Ключові слова: мінімізація витрат, використання ресурсів, матриця розподілу.

Лimepamypa: 4 [p.5]; 12; 9 [p.3]

\section{Питання для дискусії}

1. В чому відмінність понять "ризик" і "невизначеність"?

3. Назвіть та охарактеризуйте функцій ризик-менеджменту.

4. Розкрийте особливості комунікаційного процесу в ризик-менеджменті при здійснені мінімізації витрат.

5. Надайте характеристику етапу ідентифікації ресурсного забезпечення підприємства.

\section{Завдання 1.}

Проаналізувати стан економічної безпеки підприємства в підсистемі управління ризиком інноваційних проектів. Система показників для управління ризиком при здійснені мінімізації витрат інноваційних проектів представлена в табл.

Табличя

Система показників для управління ризиком інноваційних проектів

\begin{tabular}{|c|c|c|c|}
\hline Назва показника & $\begin{array}{l}\text { Підприємство } \\
\text { № } 1 \\
\end{array}$ & № 2 Підприємство & $\begin{array}{l}\text { Підприємств } \\
\text { о №3 }\end{array}$ \\
\hline $\begin{array}{c}\text { Виробничий } \\
\text { потенціал, } \\
\text { тис. грн }\end{array}$ & 17422 & 16553 & 15759 \\
\hline Коефіцієнт забезпече- & 0,00146 & 0,00673 & 0,00845 \\
\hline
\end{tabular}




\begin{tabular}{|c|c|c|c|}
\hline $\begin{array}{l}\text { ності інтелектуальною } \\
\text { власністю }\end{array}$ & & & \\
\hline $\begin{array}{l}\quad \text { Питома вага витрат на } \\
\text { обчислювальну техніку в } \\
\text { загальному об'ємі витрат на } \\
\text { інформатизацію }\end{array}$ & 0,45 & 0,56 & 0,93 \\
\hline $\begin{array}{l}\quad \text { Питома вага витрат на } \\
\text { оплату послуг сторонніх } \\
\text { підприємств у сфері } \\
\text { інформатизації в загальному } \\
\text { об'ємі витрат на } \\
\text { інформатизацію }\end{array}$ & 0,55 & 0,58 & 0,63 \\
\hline $\begin{array}{l}\text { Коефіцієнт покриття } \\
\text { капітальних інвестицій }\end{array}$ & 4,779 & 4,98 & 6,72 \\
\hline $\begin{array}{c}\text { Коефіцієнт } \\
\text { капітального будівництва }\end{array}$ & 0,0111 & 0,0528 & 0,0982 \\
\hline \begin{tabular}{l}
\multicolumn{1}{c}{ Питома вага } \\
інвестицій на будівництво в \\
загальному об'ємі \\
капітальних інвестицій \\
\end{tabular} & 0,053 & 0,067 & 0,028 \\
\hline \begin{tabular}{l}
\multicolumn{1}{c}{ Питома вага } \\
інвестицій на придбання \\
нових основних засобів у \\
загальному об’ємі \\
капітальних інвестицій
\end{tabular} & 0,947 & 0,856 & 0,724 \\
\hline
\end{tabular}

Оцінити інтегральний показник управління ризиком інноваційних проектів кожного підприємства окремо. Досліджуване підприємство № 1. Порівняти значення отриманих інтегральних показників. Запропонувати комплекс заходів щодо підвищення ефективності управління ризиком в процесі мінімізації витрат інноваційних проектів на підприємстві № 13 метою підвищення його стану економічної безпеки.

\section{ПРАКТИЧНЕ ЗАНЯТТЯ 10}

\section{Тема: Структура механізму забезпечення економічної безпеки підприємства}

Мета заняття: формування практичних навичок щодо визначення передумов існування економічної безпеки на основі критерію мінімальної прибутковості та формування практичних навичок щодо виміру рівня економічної безпеки підприємства та проведення модульної контрольної роботи за темами кредитного модуля. 


\section{План проведення заняття:}

1. Визначення мінімально необхідного рівня прибутку для забезпечення простого рівня відтворення підприємства.

2. Використання показників комерційної маржі та коефіцієнту трансформації для визначення зон формування прибутковості підприємства.

Ключові слова: аналіз прибутковості, рівень мінімального прибутку, коефицієнт комериійної маржі, коефіиієнт трансформації, зона функиіонування підприємтсва.

Лimepamypa: 1 [p. 18]; 9 [p. 4]; 10 [p.10]; 2 [p.2]

\section{Питання для дискусії}

1. Як проявляє себе інвестиційний підхід до визначення оцінки рівня економічної безпеки підприємства.

2. В чому особливість використання маркетингової стратегії при визначенні критеріїв економічної безпеки підприємства.

\section{Завдання 1.}

1. Проаналізувати балансові та економічні показники запропонованих п’яти підприємств (в табл.) за показниками мінімального прибутку, економічної рентабельності, коефіцієнта комерційної маржі (КМ) та коефіцієнта трансформацій (КТ). Визначити зони функціонування кожного iз підприємств та запропонувати стратегії подальшого функціонування на основі отриманих результатив.

Таблиия

\section{Вихідні дані для розрахунку мінімального прибутку діяльності підприємств}

\begin{tabular}{|l|c|c|c|c|c|}
\hline \multirow{2}{*}{ Показник } & \multicolumn{5}{|c|}{ Підприємство } \\
\cline { 2 - 6 } & I & II & III & IV & V \\
& & & & & \\
\hline Інфляція, \% & 19 & 19 & 19 & 19 & 19 \\
\hline $\begin{array}{l}\text { Витрати на оплату праці та } \\
\text { відрахування на соціальні заході, тис. }\end{array}$ & 27599 & 19317 & 12051 & 3233 & 2428 \\
\hline
\end{tabular}




\begin{tabular}{|l|c|c|c|c|c|}
\hline грн. & & & & & \\
\hline Амортизація, тис. грн. & 21611 & 2961 & 12154 & 845 & 143 \\
\hline $\begin{array}{c}\text { Прибуток за попередній період, тис. } \\
\text { грн. }\end{array}$ & 43341 & 14933 & -12010 & -2130 & -1028 \\
\hline
\end{tabular}

Таблиия

Вихідні дані для розрахунку комерційної маржи та коефіцієнта трансформації

\begin{tabular}{|c|c|c|c|c|c|}
\hline \multirow{2}{*}{ Підприємство } & \multicolumn{5}{|c|}{ Показник, тис. грн. } \\
\cline { 2 - 6 } & $\begin{array}{c}\text { Балансовій } \\
\text { прибуток }\end{array}$ & $\begin{array}{c}\text { Фінансові } \\
\text { витрати по } \\
\text { зобов'язанням }\end{array}$ & $\begin{array}{c}\text { Валюта } \\
\text { активу } \\
\text { балансу }\end{array}$ & $\begin{array}{c}\text { Розділ III } \\
\text { пасиву } \\
\text { балансу }\end{array}$ & $\begin{array}{c}\text { Обсяг } \\
\text { реалізації }\end{array}$ \\
\hline I & 43341 & 0 & 184730 & 0 & 703144 \\
\hline II & 14933 & 1222 & 71358 & 4270 & 162354 \\
\hline III & 0 & 12773 & 522894 & 57178 & 130942 \\
\hline IV & 0 & 1415 & 34127 & 9248 & 74133 \\
\hline V & 0 & 185 & 4892 & 599 & 21481 \\
\hline
\end{tabular}

\section{ПРАКТИЧНЕ ЗАНЯТТЯ 11}

\section{Тема: Проведення заліку 3 дисціпліни “Економічна безпека підприсмтсва"}

Мета заняття: визначення рівня успішності засвоєння студентами теоретичного та практичного матеріалу.

\section{Питання для підготовки до заліку:}

1. Економічна безпека підприємництва.

2. Структурні елементи i схема організації економічної безпеки підприємства.

3. Еволюція дослідження теми економічної безпеки підприємства.

4. Формування системи інтересів підприємства.

5. Внутрішні джерела загроз економічної безпеки підприємства.

6. Зовнішні джерела загроз економічної безпеки підприємства.

7. Порівняльна характеристика системи захисту підприємства в командно-адміністративні та перехідній економічних системах.

8. Фактори впливу та етапи оцінки фінансової складової економічної безпеки підприємства.

9. Формування системи захисту політико-правової складової економічної безпеки підприємства. 
10. Аналіз зміни факторів зовнішнього середовища на економічну безпеку підприємства.

11. Об’єкти економічної безпеки підприємства.

12. Об’єкти економічної безпеки особистості.

13. Система безпеки підприємства.

14. Служба безпеки підприємства.

15. Комерційна таємниця як об’єкт економічної безпеки підприємства.

16. Критерії оцінки економічної безпеки підприємства.

17. Методи захисту економічної безпеки особистості.

18. Суб’єкти економічної небезпеки особистості.

19. Методи захисту інформаційних потоків на підприємстві.

20. Мотивація як забезпечення кадрово - інтелектуальної складової економічної безпеки підприємства.

21. Складність оцінки екологічної складової економічної безпеки підприємства.

22. Характеристика силової складової економічної безпеки підприємства.

23. В В Влив корупції на економічну безпеку підприємства.

24. Методи оцінки рівня економічної безпеки підприємства.

25. Вплив органів державного регулювання на економічну безпеку підприємства.

26. Нормативно - правове забезпечення економічної безпеки підприємства.

27. Стратегії забезпечення економічної безпеки підприємства.

28. В В Влив перехідного економічного стану на оцінку рівня економічної безпеки підприємства.

29. Поняття промислового шпіонажу.

30. Методологія виміру рівня економічної безпеки підприємства. 
1. Економіка підприємства: Навчальний посібник / за заг. ред. П.В.Круша, В.І. Подвігіної, Б.М. Сердюка. - К.: Ельга - Н, КНТ, 2007. - 780 с.

2. Экономика предприятия / Под.ред. С.Ф. Покропивного. - К.: Знання, 2003. $608 \mathrm{c}$.

Додаткова література

3 Березин I. Промислове шпигунство, конкурентна розвідка, бенчмаркинг й етика цивілізованого бізнесу // Практичний Маркетинг. — 2005. — 22 липня. — № 101.

4. Губський Б.В. економічна безпека України: методологія виміру, стан і стратегія забезпечення. - К.: Либідь, 2000. - 122 с.

5. Демидов Б., Величко А., Волощук И. Тайный фронт // Національна безпека України. - 2005. - № 7-8. - С. 17-23.

6. Защита коммерческой тайны. Элементарные основы промышленной секретности. - СПб.: АО «Безопасность бизнеса», 1993. - 211 с.

7. Івченко О. Промислове (економічне) шпигунство: конкурентна розвідка й контррозвідка // Юридичний журнал. - 2003. - № 7.

8. Камлик M.I. Економічна безпека підприємства: економіко-правовий аспект: К.: Атака, 2005. - 432 с.

9. Козаченко Г.В., Пономарьов О.М. Економічна безпека підприємства: сутність та механізм забезпечення: Монографія. - К.: Лібра, 2003. - 280 с.

10. Мунтіян В.І. Економічна безпека України. - К.: КВТЦ, 1999.- 463 с. (розділ 3)

11. Кодекси України. Офіційні тексти. Львів: „Інтелект-Захід”, 2004. - 1024 с. 12. Сухоруков А. Методологія оцінки рівня економчної безпеки // вісник Київського національного торгово-економічного університету. - 2001. - №1. - C. $49-55$

13. Сгоров В. 3 історії розвитку промислового шпигунства // Дзеркало тижня. - 1994. - 31 грудня. - № 13. - С. 14.

14. Ярочки В. И., Халупин Д.Б. Основы защиты информации. Служба безопасности предприятия. Учебное пособие. - М.: ИнфоАрт, 1993. - 316 с 
